\title{
INTERNATIONAL POLITICS AND THE GREEK-LATIN UNION AT THE EUROPEAN CHURCH COUNCILS IN THE FIRST HALF OF THE $15^{\text {th }}$ CENTURY
}

\author{
Nikolai G. Pashkin \\ Ural Federal University, Yekaterinburg, Russian Federation
}

\begin{abstract}
Introduction. The article is aimed at studying the negotiations on the Greek-Latin Church Union at the Church Councils in Constance (1414-1418) and Basel (1431-1449), which were the predecessors of the Council of Ferrara-Florence (1438-1439) in this matter. Since they were generated by internal processes in the Latin West, they originally had not direct relationship to Byzantium. Methods and materials. The reason for the appeal of Councils to the problem of the Church Union should be sought in the field of Western international policy. It acted here as a tool for solving political problems by different actors. Analysis. At the Council of Constance the discussion of the Greek-Latin Union was initiated by Poland and Lithuania, who used it as a means of political propaganda against the Teutonic Order. The Council of Basel subsequently entered into direct negotiations with Byzantium. The reason for this was at first internecine strife in the Duchy of Lithuania, which interfered with Poland, the Teutonic Order and King Sigismund. The Council initiated consideration of the Church Union in order to support the Lithuanian Duke Švitrigaila in the struggle for the throne. As a result Byzantium was included also in the negotiations with the Council of Basel. But in 1435 Švitrigaila was defeated in the clash with Poland and its ally Duke Sigismund Kęstutaitis. This defeat undermined the influence of Sigismund of Luxembourg at the Council of Basel. The King began his rapprochement with the Pope and Venice, and the Council of Basel was influenced by their political rivals, such as Milan and France. The theme of the Church Union at the Council became an instrument of struggle for political interests between these groups of political subjects. As a result, the struggle led to sharp disputes over the choice of the place for the Greek-Latin Council. The main options were Italy and French Avignon. The Byzantines chose the first option. But Byzantium was not the subject of the policy that created the situation of this choice. In the West this policy has led to significant changes. Results. The results of the negotiations on the Church Union at the Council of Basel displayed the fall of the role of imperial policy in the Latin West, which was represented by the King and Emperor Sigismund Luxembourg. The Empire was losing control of Italy. The result was the withdrawal of the papacy from its influence and the strengthening of Venice. Their union stood behind the Council of Ferrara-Florence. Outside Italy this Council has not received recognition.
\end{abstract}

Key words: Church Councils, Council of Constance, Council of Basel, Church Union, Byzantium, Poland, Lithuania, Teutonic Order, Holy Roman Empire.

Citation. Pashkin N.G. International Politics and the Greek-Latin Union at the European Church Councils in the First Half of the $15^{\text {th }}$ Century. Vestnik Volgogradskogo gosudarstvennogo universiteta. Seriya 4. Istoriya. Regionovedenie. Mezhdunarodnye otnosheniya [Science Journal of Volgograd State University. History. Area Studies. International Relations], 2020, vol. 25, no. 6, pp. 274-284. (in Russian). DOI: https://doi.org/10.15688/ jvolsu4.2020.6.22

УДК 94“04/14”:327

Дата поступления статьи: 27.06.2019

ББК 63.3(0)41-6

Дата принятия статьи: 09.09.2019

\section{МЕЖДУНАРОДНАЯ ПОЛИТИКА И ГРЕКО-ЛАТИНСКАЯ УНИЯ НА ЕВРОПЕЙСКИХ ЦЕРКОВНЫХ СОБОРАХ ПЕРВОЙ ПОЛОВИНЫ ХV ВЕКА}

\author{
Николай Геннадьевич Пашкин
}

Уральский федеральный университет, г. Екатеринбург, Российская Федерация 
Аннотация. Целью статьи является исследование переговоров о греко-латинской унии на церковных соборах в Констанце (1414-1418) и Базеле (1431-1449), которые были предшественниками Ферраро-Флорентийского собора (1438-1439) в этом вопросе. Поскольку они были порождены внутренними процессами на латинском Западе, то прямого отношения к Византии первоначально не имели. В связи с этим причину их обращения к проблеме унии следует искать в области западной международной политики. Проблема унии выступала здесь как инструмент решения политических задач разными субъектами. На Констанцском соборе обсуждение греко-латинской унии было инициировано Польшей и Литвой, которые использовали это как средство политической пропаганды против Тевтонского ордена. В прямые переговоры с Византией вступил впоследствии Базельский собор. Поводом к этому сначала стала междоусобица в княжестве Литовском, в которую вмешивались Польша, Тевтонский орден и германский король Сигизмунд (1410-1437). Собор инициировал рассмотрение церковной унии с целью поддержать литовского князя Свидригайло (1430-1432) в борьбе за престол. В результате в переговоры он включил и Византию. Но Свидригайло в 1435 г. потерпел поражение в столкновении с Польшей и ее союзником князем Сигизмундом Кейстутовичем (1432-1440). Это поражение подорвало влияние на Базельском соборе Сигизмунда Люксембурга. Король начал сближение с папой и Венецией, а Базельский собор оказался под влиянием их политических соперников, таких как Милан и Франция. Тема церковной унии на Базельском соборе стала в конечном счете инструментом борьбы за политические интересы между этими группами политических субъектов. Борьба привела к острым спорам по вопросу о выборе места для греко-латинского собора. Основными вариантами стали Италия и французский Авиньон. Византийцы выбрали первый вариант. Но сама Византия не была субъектом той политики, которая создала ситуацию этого выбора. Результаты переговоров о церковной унии на Базельском соборе зафиксировали падение роли имперской политики на латинском Западе, которую представлял король и император Сигизмунд Люксембург. Империя теряла контроль над Италией. Результатом был выход папства изпод ее влияния и укрепление Венеции. Их союз стоял за Ферраро-Флорентийским собором, который за пределами Италии признания не получил.

Ключевые слова: церковные соборы, Констанцский собор, Базельский собор, церковная уния, Византия, Польша, Литва, Тевтонский орден, Священная Римская империя.

Цитирование. Пашкин Н. Г. Международная политика и греко-латинская уния на европейских церковных соборах первой половины XV века // Вестник Волгоградского государственного университета. Серия 4, История. Регионоведение. Международные отношения. - 2020. - Т. 25, № 6. - С. 274-284. - DOI: https:// doi.org/10.15688/jvolsu4.2020.6.22

Введение. Проблема церковной унии между Константинополем и Римом является одной из самых значимых тем в изучении последнего периода истории Византии. Между тем переговоры по этому вопросу, увенчавшиеся подписанием унии на Ферраро-Флорентийском соборе (1438-1439), имели свое начало на соборах в Констанце (1414-1418) и Базеле (1431-1449), а сам собор во Флоренции явился как альтернатива в противовес последнему. Византию уния интересовала как средство против турецкого завоевания. Но вопрос заключается и в том, что Констанцский и Базельский соборы были порождены историческими процессами на латинском Западе, которые к восточной церкви и Византии отношения не имели. И все же униатская тематика, которая неизбежно продуцировала контакты между Западом и Византией, на этих соборах имела место.

Методы и материалы. На сегодняшний день достаточно хорошо изучены непос- редственно греко-латинские контакты и переговоры, состоявшиеся в Констанце и Базеле [2; 23]. Но проблема смотрится несколько иначе, если сами названные соборы рассматривать сквозь призму международных отношений в Европе первой половины XV века. В этом смысле латинская сторона никак не может быть признана единым субъектом переговоров, так же как и сама западная церковь. Как известно, Констанцский собор был созван в условиях так называемой Великой западной схизмы (1378-1417), которая только на этом соборе официально завершилась. Следовательно, собор, а не папа, был субъектом переговоров от имени церкви. При этом собор одновременно был и форумом, где методами церковной дипломатии велась борьба между разнообразными участниками международной политики. А инициированная в Констанце попытка реформы церкви, подразумевавшая подчинение папской власти собору, имела следствием то, что впоследствии Ба- 
зельский собор и папа действовали как два самостоятельных субъекта, в том числе на переговорах с Константинополем, оспаривая друг у друга это право. Под таким углом зрения готовившееся воссоединение церквей Запада и Востока выглядит многослойным процессом, в котором переплетались и сталкивались интересы не двух, то есть Рима и Константинополя, а множества субъектов европейской политики. Возникает вопрос, какие мотивы действительно стояли за выдвижением проблемы унии на означенных соборах и в какой степени Византия сама была субъектом этого процесса. Именно анализ стоявших за ним международных отношений поможет нам в этом разобраться.

Анализ. Тот факт, что отношения латинской и греческой церквей вызывают интерес на Западе исключительно как инструмент международной политики, был в полной мере продемонстрирован уже историей Констанцского собора. В условиях западной схизмы, ввиду отсутствия общепризнанного главы римской церкви, этот собор своим созывом был обязан германскому королю и будущему императору Сигизмунду Люксембургу (14101437, император с 1433 г.), бывшему одновременно венгерским королем с 1387 г. [10]. За три года до начала собора вопрос о перспективах греко-латинской унии был поднят в письме Сигизмунда к византийскому императору Мануилу II Палеологу (1391-1425) [7, S. 391394]. Из текста послания следовало, что предварительно этот вопрос король обсуждал с папой Иоанном XXIII (1410-1415), о чем был осведомлен находившийся с миссией на Западе византийский дипломат Мануил Хрисолора. Автор призывал императора в Константинополе к переговорам о времени и месте для совместного церковного собора, а также выражал намерение в скором времени совершить поход против турок, к которому предлагал присоединиться. Между тем на подлинные намерения Сигизмунда, предопределившие его интерес к Византии, указывает тот факт, что главной его проблемой в тот момент были не турки, а отношения с Венецией [26, S. 4-31]. Впереди его ожидало по-настоящему фундаментальное противоборство с этой итальянской республикой [28]. Формальной причиной назревавшего конфликта был ее спор с венгерской короной о принадлежности портов Далмации, но истинный размах противостояния был гораздо шире. Как показывают специальные изыскания, в дальнейшем речь шла о политике короля, направленной на вытеснение венецианского торгового капитала со всего континентального рынка Европы, и упорных попытках наладить независимую от Венеции трассу в страны Ближнего Востока и Китай через Дунай, Черное море и генуэзские колонии Крыма [18]. В связи с этим Византия рассматривалась им как одно из звеньев торговой блокады своего главного геополитического противника, а потому униатская тематика могла стать способом зондирования почвы для политического союза. До осени 1411 г. противоречия Сигизмунда с Beнецией еще оставались в рамках дипломатических баталий, но по времени они совпали с начавшейся на Востоке борьбой за османский престол между наследниками султана Баязида I (1389-1402). Турецкая междоусобица 1409-1413 гг. несла на себе явный отпечаток тех противоречий. Вовлечение в нее Константинополя создавало военно-политические риски для Византии. Объективно это было выгодно именно Венеции, так как затрудняло Сигизмунду саму возможность использовать Восточную империю в качестве союзника. Отсюда становится ясно, что план войны с турками, о котором Сигизмунд писал императору, вместе с идеей церковной унии был также порожден его стратегией, обращенной против республики [5, с. 233-234].

В октябре 1411 г. конфликт короля с Венецией перешел в военную фазу. В результате в следующем письме к византийскому императору он уже открыто призывал Константинополь вступить в военный союз с ним и принять прямое участие в действиях против венецианцев [7, S. 394-399]. Для достижения этой цели Сигизмунд вновь предлагал обсудить вопрос о церковной унии. Столкновение с Венецией, однако, в планы Византии не входило, а тем временем на Западе началась подготовка к церковному собору. После достигнутого весной 1413 г. перемирия короля с республикой вопрос о времени и месте его проведения был решен. Согласно официально заявленным задачам, собору предстояло закончить латинскую схизму, что он впоследствии 
и сделал, склонив к добровольному отречению либо низложив сразу трех конкурирующих антипап - Григория XII (1406-1415), Бенедикта XIII (1394-1417) и Иоанна XXIII (1410-1415). Это открывало широкие возможности для светской власти, которая в лице германского короля стояла у истоков собора. Фактически он был нужен Сигизмунду как одно из средств создания международной коалиции. Помимо контактов о возможном союзе с Византией, аналогичные переговоры велись с королями Англии, Франции, Дании, Арагона [27]. В свете предыдущих событий вынесение вопроса о церковной унии на предстоящий собор могло быть ожидаемым. Однако в приглашении, отправленном в 1414 г. в Константинополь за несколько месяцев до его начала, Сигизмунд ничего не говорил на эту тему [7, S. 399-401]. Судя по всему, королю уже было понятно, что участвовать в его политике Византия не будет. Византийские дипломаты все же появились на Констанцском соборе, но в результате проблема церковной унии получила здесь своеобразное развитие.

В июле 1415 г. Сигизмунд уже как фактический император Запада и политический руководитель собора огласил его главные задачи. Помимо собственно той, ради которой собор формально и был созван, то есть ликвидации схизмы в западной церкви, в его речи звучал призыв к прекращению войны Англии с Францией и конфликта между Польшей и Тевтонским орденом $[11, \mathrm{~S} .152]$. О церковной унии с Востоком король и здесь тоже умолчал, хотя до весны 1415 г. в Констанце находился византийский посол Мануил Хрисолоpa. Но и византийская дипломатия на Констанцском соборе не проявила стремления к обсуждению вопроса [2, с. 59-63]. Объяснение этому опять же можно найти в том, что участвовать в конфликте Сигизмунда с Венецией Византия не стремилась. Еще в конце 1413 г. император Мануил II предложил Венеции посредничество в его урегулировании, которое сенат отклонил [15, № 3335; 2, с. 33]. Между тем, как уже было замечено, сама вероятность переговоров о церковной унии была обозначена Сигизмундом именно в контексте его политики, направленной против республики. В силу нейтральной позиции, занятой Византией, в Констанце эта тема стала для ви- зантийцев несвоевременной, а для короля - неактуальной. Совсем другой субъект начал выносить ее на обсуждение. Этим субъектом стала Польша.

Сигизмунд не случайно в упомянутой речи перед собором проявил интерес к англофранцузскому и польско-тевтонскому конфликтам. Англия была для него ценным потенциальным союзником в торговой политике против Венеции. Еще в 1412 г. за такой союз он предлагал выгодное посредничество в прекращении Столетней войны английскому королю Генриху IV (1399-1413) [28, S. 163]. Еще более актуальным для него был польско-тевтонский конфликт, в котором он тоже пытался играть роль посредника. Сигизмунд не мог быть безучастным к попыткам Польши укрепиться на Балтийском побережье. Имели место также серьезные противоречия между ними из-за влияния в Восточной Европе. Однако прямого конфликта с Польшей германский король стремился избежать, вследствие чего инициатива в вопросе унии оказалась у нее в руках. Как оказалось, церковный собор открывал широкие возможности для использования религиозной пропаганды в качестве политического оружия, чем искусно воспользовалась польско-литовская сторона. Если орден обвинял Польшу и Литву в том, что в их лагере против тевтонских рыцарей воюют «схизматики» из русских земель, то ответом другой стороны явилось немедленное предложение собору о содействии церковной унии с Востоком и решении проблемы схизмы как таковой [4, с. 323-324]. Осенью 1415 г. письма с соответствующим содержанием Констанцский собор получил от польского короля Владислава II Ягеллона (1386-1434) и литовского князя Витовта (1392-1430) [12, p. 331332]. Поляки давали тем самым понять, что военные средства для укрепления церкви, которые идеологически оправдывали само существование Тевтонского ордена, более не нужны. Польша своей пропагандой действительно нанесла тяжелый урон репутации ордена как якобы главного форпоста католицизма на Востоке. Косвенно исход этой борьбы повлиял и на прочность позиций короля Сигизмунда. Проблема унии, которую поляки повернули против тевтонцев, обещала передать посредническую роль в их отношениях папе. 


\section{ВИЗАНТИЙСКОЕ ПРАВОСЛАВИЕ}

Им стал избранный на Констанцском соборе в 1417 г. Мартин V (1417-1431), к тому же венецианец по происхождению. После этого, по общему признанию исследователей данного события, германский король, являвшийся в самом начале лидером собора, потерял нити управления им.

Новый папа проявил интерес к вопросу об унии с Византией, обусловленный в значительной мере стремлением укрепить позиции папства в западном мире после недавнего окончания латинской схизмы. Соответствующие переговоры между ним и Константинополем были начаты после завершения Констанцского собора. При этом по-настоящему история этих переговоров получила продолжение, когда к ним подключился Базельский собор, созванный при его преемнике - папе Евгении IV (1431-1447). Сам понтифик на соборе в Базеле ни разу не появился. В силу декретов, принятых в Констанце, собор играл самостоятельную роль. Однако сначала он находился под влиянием короля Сигизмунда. Тот же в свою очередь добивался от папы императорской короны. Самого папу поддерживала Венеция, являвшаяся наиболее грозным соперником германского и венгерского короля. Этот расклад сил на международной арене предопределит дальнейшие события, которые прямо или косвенно касались проблемы унии церквей.

С точки зрения международных отношений проблема греко-латинской унии в истории Базельского собора имеет немаловажное значение. Спустя семь лет после открытия форума именно она спровоцировала его роспуск папой. Это событие явилось предпосылкой к Ферраро-Флорентийскому собору, который и завершил переговоры с Византией, одновременно вызвав на Западе новый церковный раскол. При этом первоначально контакты с греками в Базеле не планировались. В интересах короля Сигизмунда собор пытался найти компромисс с гуситами, и только политические обстоятельства заставили его вдобавок заняться еще и унией с Востоком. Если папа по этому вопросу уже вел переговоры с Константинополем, то в Базеле проблема «восточной схизмы» снова привлекла к себе внимание под влиянием событий в польско-литовском государстве. За год до открытия собора после смерти князя Витовта в Литве началась усобица за освободившийся престол. В борьбу вступили, с одной стороны, его младший брат Сигизмунд Кейстутович, поддержанный королем Польши Владиславом II, с другой - младший брат короля Свидригайло Ольгердович. Последнему удалось установить власть на большей территории княжества. Еще Витовт взял здесь курс на укрепление автономии, но так и не довел его до конца. Он не успел получить уже изготовленную для него королевскую корону. Свидригайло же в отстаивании своих прав, поддержанных значительной группой литовско-русской православной знати, начал политику полной независимости от Польши. В проведении этой политики он приобрел естественных союзников в лице короля Сигизмунда Люксембурга и Тевтонского ордена [21, S. 89-92]. Представитель последнего на Базельском соборе начал защищать интересы литовского князя в его конфликте с Польшей [17]. В качестве политико-пропагандистского средства Свидригайло также избрал тему церковной унии, предложив Базельскому собору осуществить ее на русских землях Великого княжества Литовского. Находившийся под влиянием Люксембурга собор предложение поддержал. Теперь пропаганда унии работала против Польши. Поддерживая врагов Свидригайло, она рисковала предстать стороной, препятствующей «святому делу борьбы со схизмой». Кроме того, от короля Сигизмунда шли обвинения ее в тайном покровительстве чешским гуситам, которые польские послы в Базеле, впрочем, упорно отрицали. Обратной стороной стал тот факт, что униатская и гуситская тематика для Базельского собора в этот момент соединились. Позднее это станет причиной гневной реакции греков.

В самом деле, поддержка инициативы Свидригайло побуждала Базельский собор выходить на переговоры и с Византией, которые тогда уже вел папа и считал их своей исключительной прерогативой. Используя повод для начала таких переговоров, предоставленный литовским князем, в Базеле руководствовались и своими соображениями. Принимая переговоры с Константинополем на себя, Базельский собор лишал понтифика возможности самостоятельно созывать новый, уже гре- 
ко-латинский собор: в Базеле понимали, что созыв последнего будет автоматически означать роспуск первого. Два Вселенских собора одновременно были невозможны. В связи с этим в октябре 1431 г. Базельский собор рекомендовал папе обратиться к польскому королю Владиславу II и литовскому князю Свидригайло с призывом прекратить их взаимную вражду и начать переговоры о церковной унии (ad reducendum Ruthenos) именно с собором [21, S. 89]. Одновременно шла речь и о том, чтобы аналогичное приглашение папа отправил византийскому императору Иоанну VIII Палеологу (1425-1449), так как без участия Византии такие переговоры не могли иметь смысла. Но результат оказался обратный ожидаемому: через два месяца папа попытался распустить Базельский собор именно под тем предлогом, что для церковной унии с греками он созывает новый Вселенский собор в Болонье. Попытка распустить неугодный ему собор не удалась. В Базеле отказали папе в этом праве, а на выдвинутое им основание для роспуска председатель собора кардинал Чезарини якобы ответил, что «уния с греками - старая песня, которую поют уже триста лет и каждый год» (ista cantilena de grecis iam tricentis annis duravit et omni anno renovatur) [25, p. 105].

Польша извлекла определенную выгоду из сложившейся ситуации. Пока понтифик не отозвал свое решение (до декабря 1433 г.), она могла без ущерба своей репутации игнорировать Базельский собор и его политику в вопросе о схизме, которая работала в тот момент на имидж Свидригайло и его союзников короля Сигизмунда и ордена. Идеологически союз этих трех сторон выступал на Базельском соборе как сила, которая стоит на страже интересов церкви, заключающихся в борьбе со схизмой Востока и с ересью гуситов. За это время польский ставленник Сигизмунд Кейстутович, сумевший укрепиться на части территории Литвы, использовал более прагматичное средство. В октябре 1432 г. им были пожалованы привилегии православной аристократии Великого княжества Литовского, значительно уравнивающие ее в политических правах с католиками. Таким образом, потенциальная привлекательность церковной унии для нее сильно обесценилась. Противо- положной стороне в этой ситуации оставалось только показать, что православные в Литве, напротив, заинтересованы в унии, и предпринять шаги к реальному ее исполнению. Эти шаги, однако, требовали от собора перейти к прямым переговорам с Константинополем в обход курии, так как два года между Базельским собором и папой Евгением IV, объявившим о его роспуске, сохранялись отношения взаимного непризнания. В результате в янваpe 1433 г. из Базеля в Византию отправилось первое посольство. Самим же грекам вскоре предстояло узнать, что обсуждать эту тему отныне можно не только с папой. Между Базелем и Константинополем начались контакты. 14 июля 1434 г. с византийскими послами Базельский собор заключил договор о практической подготовке унии церквей [13, S. 478482]. Примечательно, что в преамбулу к договору тогда попала формулировка о намерениях собора завершить «старый раскол с греками и новый - с богемами» (recens Bohemorum antiqumque Grecorum dissidium prorsus extinquere). Эта оговорка, приравнивавшая византийцев к еретикам-гуситам, впоследствии сильно возмутила императора и патриарха, потребовавших переписать текст. Дипломаты из Базеля оправдывались, списывая все на случайность, но едва ли это было так. Сказанное выше скорее указывает на следы той пропаганды, которая в то время задавала саму проблему церковной унии в Базеле в интересах коалиции Свидригайло, короля Сигизмунда и ордена.

Параллельно контактам с Базельским собором со стороны князя Свидригайло были приняты меры, которые должны были демонстрировать якобы реальное стремление к унии в западнорусских землях. В марте 1433 г., через два месяца после отъезда базельского посольства в Константинополь, собору было адресовано послание из Витебска. Шестнадцать представителей местной православной знати выражали поддержку намерениям своего князя объединить греческую и римскую церкви. Политический мотив этих намерений прозвучал в письме к собору от магистра Тевтонского ордена: в нем утверждалось, что для победы над схизмой Свидригайло нуждается в поддержке своих прав на Литву. Оба послания были зачитаны в Базеле в июне 1433 года. 


\section{ВИЗАНТИЙСКОЕ ПРАВОСЛАВИЕ}

Еще через месяц обращение к собору направил из того же Витебска сам литовский князь, хотя оно достигло его только в декабре [17, S. 124-125]. За это время ситуация успела перемениться. В конце 1433 г. Польша вынудила орден заключить с ней двенадцатилетнее Ленчицкое перемирие, по которому он расторгал союз с Свидригайло. Хотя оно не было признано германским королем Сигизмундом Люксембургом и поэтому не вступило в силу, для Польши это была дипломатическая победа. Политическая ответственность за продолжение конфликта теперь была на ее противниках. Позиции Свидригайло в Литве на этом фоне тоже слабели. Вдобавок ему уже было трудно укреплять свой имидж пропагандой приверженности делу церковной унии: с 1434 г. главным партнером для Базельского собора в переговорах по этому вопросу могла быть только Византия, а не Литва. О шаткости его положения свидетельствовал заговор, который закончился жестокой расправой князя над киевским митрополитом Герасимом (1433-1435) [1, с. 137]. Это лишь сильнее оттолкнуло от него православную знать. Наконец, в сентябре 1435 г. его армия, негласно укрепленная тевтонцами, была разгромлена поляками и их литовскими союзниками в битве у Вилькомира. Свидригайло навсегда бежал из Литвы, проиграв своему сопернику князю Сигизмунду Кейстутовичу, а орден был вынужден заключить с Польшей Брест-Куявский мирный договор (декабрь 1435 г.).

С 1435 г. литовский фактор больше не участвовал в решении вопроса о церковной унии на Базельском соборе. Но начатые во многом под его влиянием переговоры с Византией собор не мог прекратить, так как изменившийся международно-политический контекст включил новые факторы. Исход междоусобицы в Литве и результаты польско-тевтонской войны подвели итог неудачным попыткам короля и императора Сигизмунда Люксембурга с помощью ордена и Свидригайло расколоть федерацию Польши и Великого княжества Литовского. Этим наносился удар по его позициям в Восточной Европе, которые и без того были шаткими. Не сумев решить на Базельском соборе задачи своей региональной политики, Сигизмунд начал терять влияние на его решения в других вопро- cax. В результате начала разрушаться создаваемая им прежде система отношений на западе континента. В 1435 г. при посредничестве Базельского собора был заключен Аррасский договор, завершивший во Франции войну между короной и герцогом Бургундским. Этот договор официально лишил Сигизмунда влияния на французского короля и ослабил позиции империи в непростых отношениях с Бургундией $[6$, с. 46]. На этом фоне важнейший поворот происходил и в такой ключевой сфеpe, как отношения с Венецией. Многолетнее противостояние в 1435 г. закончилось подписанием мира, основанного на уступках морской республике. Мирный договор подразумевал также заключение союза этих сторон против турок [9, S. 41]. Необходимость в таком союзе назревала уже давно, но интересы торговой политики и связанного с империей купеческого капитала долгое время оказывались выше нее. Возможно, перелом начался уже после 1430 г., когда турки отвоевали у венецианцев Фессалонику и начали угрожать не только ее позициям в Далмации, но и Белграду, который прикрывал подступы к Венгрии, являвшейся фамильным владением Сигизмунда [22, p. 370-371]. Примирение короля с Венецией в свою очередь происходило при посредничестве папы Евгения IV, тоже венецианца по происхождению, который в 1433 г. короновал его, наконец, императорской короной. В ответ Сигизмунд убедил Базельский собор прекратить раскол с понтификом, возникший в 1432 г. из-за попытки роспуска. Но этим же он отдалился от немецких курфюрстов, которым независимый от папы собор был выгоден для проведения церковной реформы. В дальнейшем Базельский собор и будет искать поддержку среди них.

Вышеизложенные факты опосредованно касались переговоров о греко-латинской унии на Базельском соборе. В совокупности они означали ослабление роли имперской политики на Западе, которую тогда представлял Сигизмунд Люксембург. Последующий исход Базельского собора, означавший крах соборного движения за церковную реформу, сопровождался подрывом института империи как носителя универсалистских функций наряду с папством [8, S. 577]. Правление Люксембурга демонстрирует его тем, что с середины 
1430-х гг. он окончательно поменял приоритеты: интересы венгерской короны значили для него теперь больше императорской. Его союз с Венецией требовал от него лояльной политики по отношению к папе и отказа от безоговорочной поддержки Базельского собора, что лишь ускорило потерю контроля над ним. Это заметно отразилось на ситуации в Италии. Папство, выходившее из-под влияния императорской короны, политически сближалось с Венецией, против которой выступали Генуя и Милан, причем в отношения итальянских государств на стороне последних активно начинала входить Франция. В 1437 г. уже можно было говорить о складывании двух коалиций: императора Сигизмунда, Венеции, Флоренции и папы, с одной стороны, и коалиции Франции, Милана и Генуи - с другой. Базельский собор стал первым местом столкновения их интересов [19, S. 259-264]. Поводом стал как раз вопрос об унии с греками. Поэтому в ходе переговоров, которые собор уже вел с Византией, новые векторы международных отношений в Европе вызвали кризис по безобидному, на первый взгляд, вопросу - о выборе места встречи латинской и греческой сторон [2, с. 106-123; 20, S. 626-638]. Здесь столкнулись интересы не Византии и Запада как единого субъекта, а позиции нескольких субъектов внутри западного политического мира.

Условие греков было только в том, что местом заключения унии не может стать сам Базель, так как для этого собор должен быть созван заново согласно древним, а не принятым в западной церкви канонам. С этим западная сторона переговоров согласилась, но раскололась в выборе вариантов. Анализ этих вариантов как раз и соответствовал вышеупомянутой перестановке в европейской политике. Во-первых, инициатива шла от императора Сигизмунда, который уже отдалился от Базельского собора и не имел прежнего влияния в нем, но еще пытался дистанцироваться от папы и укрепить свои позиции посреднической функцией между собором и понтификом. Этим объясняется его предложение сделать свою столицу Буду местом проведения Вселенского греко-латинского собора. Современный немецкий специалист по истории церковных соборов Й. Хельмрат обратил внимание, что до этого важнейшие в XV в. соборы считались политическим успехом Сигизмунда как императора именно потому, что они состоялись в имперских городах - Констанце и Базеле [20, S. 615]. На контрасте с этим Буда явно подчеркивала скорее его статус как венгерского короля. Но зато это была уступка папе, для которого «имперские» церковные соборы не могли не ассоциироваться с реформой церкви, ведущей к ограничению политического значения папства.

Во-вторых, Буда была альтернативой другому неожиданно появившемуся варианту - французскому Авиньону. Этот вариант объединил интересы противоположной коалиции. В Италии ее представлял Милан, направленный против Венеции, а за Альпами - французская корона в противовес империи. Здесь обращает на себя внимание, что за Авиньон проголосовали не только французская, но и германская так называемые нации на Базельском соборе, составившие его большинство. Это свидетельствовало о сильной оппозиции Сигизмунду в империи со стороны князей. Показательны и те идеологические аргументы, с которыми Сигизмунд и его сторонники протестовали против выбора Авиньона. В письме к курфюрстам в 1437 г. он заявлял, что французы якобы затевают Вселенский собор в своем городе, чтобы устроить повторное «авиньонское пленение пап», а вместе с папами готовятся перенести к себе императорскую корону, отняв ее у немцев [14, S. 235-236]. Если отвлечься от формы этих обвинений, то за ней просматривается поражение имперской политики Сигизмунда в Европе, берущее начало еще на Констанцском соборе. Через несколько лет это закончится тем, что император Фридрих III (1440-1493) уже как обычный территориальный правитель, подобно князьям, заключит с папой так называемый Венский конкордат (1448 г.) о разграничении прав в церкви и окончательно закроет тему церковной реформы, поднятую однажды соборами в Констанце и Базеле [8, S. 576].

Третьей альтернативой в выборе места для униатского собора была Италия. Проголосовавшая за нее меньшая часть Базельского собора в результате вышла из него, позволив тем самым папе объявить созыв нового собора для встречи с греками. В выборе Италии были заинтересованы как сам папа, 


\section{ВИЗАНТИЙСКОЕ ПРАВОСЛАВИЕ}

так и его главный на тот момент политический союзник - Венеция. С учетом того, что политика императора Сигизмунда строилась теперь на компромиссе с ними, его вариант с венгерской Будой едва ли мог соперничать с этим. Местом собора в итоге стала Феррара, а затем - Флоренция. Одним из современников, кто сумел оценить происходившее тогда под видом борьбы за Вселенский греко-латинский собор, был Эней Сильвий Пикколомини (будущий папа Пий II, 1458-1463). В письме к императору Сигизмунду он уверял, что собор в Италии нужен гвельфам - врагам империи на итальянской земле. По его словам, он был выгоден и венецианцам в их стремлении подчинить своему влиянию и папский престол, и империю [16, р. 63-65]. Автор тем самым ясно заметил, что связь империи с папством основана на универсализме обоих институтов и без этой связи они оба его и потеряют. Его взгляд вскоре подтвердился. Поддержка венецианцев была для папы принципиально важной после того, как его сторонники в Базеле спровоцировали раскол по вопросу о выборе места для униатского собора. Борьба закончилась в Константинополе в 1437 г., куда почти одновременно успели прибыть корабли из Венеции и Авиньона. Первые действовали от лица папы, вторые - от имени Базельского собора, низложившего его своим решением. Как известно, в выигрыше оказались итальянцы. Византийцы не представляли себе унию на Bceленском соборе, который не будет признан папой. Формально они сделали свой выбор, но такое решение было им навязано международной ситуацией на Западе, в создании которой они не участвовали.

Результаты. Вопрос о греко-латинской церковной унии в Констанце и Базеле возникал не из двусторонних отношений Византии и Запада, а как один из инструментов международной политики на Западе, субъектом которой Византия не являлась. Результаты именно этой политики во многом и зафиксировал Ферраро-Флорентийский собор. В политическом отношении он продемонстрировал разобщенность Запада и прежде всего падение значимости императорской власти как политического института, который во многом держался на ее способности контролировать Италию и папство. Не подкрепленный ее ав- торитетом этот собор, в отличие от соборов в Констанце и Базеле, имел ограниченное признание в самой Италии и совсем не получил его севернее Альп [24]. Эволюция института империи вскоре стала одним из признаков меняющейся архитектуры международных отношений позднего Средневековья [3].

\section{СПИСОК ЛИТЕРАТУРЫ}

1. Греков, И. Б. Очерки по истории международных отношений Восточной Европы XIV-XVI вв. / И. Б. Греков. - М. : Изд-во вост. лит., 1963. - 376 с.

2. Пашкин, Н. Г. Византия в европейской политике первой половины XV в. (1402-1438) / Н. Г. Пашкин. - Екатеринбург : Изд-во Урал. ун-та, 2007. - 238 с.

3. Пашкин, Н. Г. Падение Константинополя и кризис идеологии имперского универсализма на латинском Западе / Н. Г. Пашкин // Известия Уральского федерального университета. Серия 2, Гуманитарные науки. - 2012. - Т. 14, №2 (102). - С. 109-117.

4. Пашкин, Н. Г. Греко-латинская уния на Констанцском соборе в зеркале польско-тевтонских отношений / Н. Г. Пашкин // Античная древность и Средние века. - 2015. - Вып. 43. - С. 320-328. - DOI: https://doi.org/10.15826/adsv.2015.43.019.

5. Пашкин, Н. Г. Османское «междуцарствие» 1402-1413 гг. : международно-политический аспект / Н. Г. Пашкин // Античная древность и Средние века. - 2018. - Вып. 46. - С. 225-240. - DOI: https:// doi.org/10.15826/adsv.2018.46.015.

6. Черкасов, Д. Н. Аррасский договор 1435 г. в истории дипломатии Столетней войны / Д. Н. Черкасов // Журнал международного права и международных отношений. - 2012. - № 4. - С. 43-48.

7. Acta Concilii Constanciensis / ed. H. Finke.Münster : Druck und Verlag der Regensburgschen Buchhandlung, 1896. - 444 S.

8. Angermeier, H. Das Reich und der Konziliarismus / H. Angermeier // Historische Zeitschrift. - 1961. - Bd. 192. - S. 541-584.

9. Baum, W. Europapolitik im Vorfeld der Frühen Neuzeit : König und Kaiser Sigismund vom Hause Luxemburg, Ungarn, Byzanz und der Orient / W. Baum // Europa in der Frühen Neuzeit. Bd. 1. Vormoderne / hrsg. von E. Donnert. - Weimar : Verl. Böhlau, 1997. -S. 13-41.

10. Boockmann, H. Zur politischen Geschichte des Konstanzer Konzils / H. Boockmann // Zeitschrift für Kirchengeschichte. - 1974. - Bd. 85. - S. 45-63.

11. Brandmüller, W. Das Konzil von Konstanz. Bd. 2. Bis zum Konzilsende / W. Brandmüller. Paderborn : Schöningh, 1997. - 429 S.

12. Codex epistolaris Vitoldi Magni ducis Lithuaniae, 1376-1430 / ed. byA. Prochaka. - Krakow : Academia Literarum, 1882. -1113 p. 
13. Dekrete der ökumenischen Konzilien. Bd. 2. Konzilien des Mittelalters / hrsg. von J. Wohlmuth. Paderborn : Schöningh, 2000. -655 S.

14. Deutsche Reichstagsakten / hrsg. von G. Beckmann. - Gotha : Friedrich Andreas Perthes, 1957. $-427 \mathrm{~S}$.

15. Dölger, F. Regesten der Kaiserurkunden des oströmischen Reiches von 565 bis 1453. T. 5 / F. Dölger. München ; Berlin : Verl. C.H. Beck, 1965. - 138 S.

16. Enea Silvio Piccolomini. Opera inedita / ed. by J. Cugnoni. - Roma : Accademia Nazionale dei Lincei, 1883. $-371 \mathrm{p}$.

17. Forstreuter, K. Der Deutsche Orden und die Kirchenunion während des Basler Konzils / K. Forstreuter // Annuarium Historiae Conciliorum. 1969. - Vol. 1. - S. 114-139.

18. Heimpel, H. Zur Handelspolitik Kaiser Sigismunds / H. Heimpel // Vierteljahrschrift für Sozialund Wirtschaftsgeschichte. - 1930. - Vol. 23. S. 145-156.

19. Helmrath, J. Das Basler Konzil 1431-1449 : Forschungsstand und Probleme / J. Helmrath. - Köln : Böhlau, 1987. - 656 S.

20. Helmrath, J. Locus Concilii. Die Ortswahl für Generalkonzilien vom IV Lateranum bis Trient/J. Helmrath // Annuarium Historiae Conciliorum. - 1995/1996. Vol. 27/28. - S. 593-662.

21. Jablonowski, H. Westrussland zwischen Wilna und Moskau: Die politische Stellung und die politischen Tendenzen der russischen Bevölkerung des Grossfürstentums Litauen im 15. Jh. / H. Jablonowski. Leiden : E. J. Brill, 1955. - 167 S.

22. Kissling, H. J. Venedig und der islamische Orient bis 1500 / H. J. Kissling // Venezia e il Levante fino al secolo XV. Vol. 1 / ed. by A. Pertusi. - Firenze : Olschki, 1973. - P. 361-387.

23. Leidl, A. Die Einheit der Kirchen auf den spätmittelalterlichen Konzilien: von Konstanz bis Florenz / A. Leidl. - Paderborn : Verl. BonifaciusDruckerei, 1966. - 233 S.

24. Meuthen, E. Eugen IV, Ferrara-Florenz und der lateinische Westen / E. Meuthen // Annuarium Historiae Conciliorum. - 1990. - Bd. 22. - S. 219-233.

25. Monumenta Conciliorum Generalium saeculi decimi quinti. Bd. 2 / ed. F. Palacký. - Wien : Typ. Aulae et Status, $1873 .-1224 \mathrm{p}$.

26. Schiff, O. König Sigmunds italienische Politik bis zur Romfahrt (1410-1431) / O. Schiff. - Frankfurt/M : Verl. von Joseph Bauer, 1909. - 155 S.

27. Schoenstedt, F. König Siegmund und die Westmächte 1414-1415 / F. Schoenstedt // Die Welt als Geschichte. - 1954. - Bd. 14. - S. 149-164.

28. Stromer, W. Landmacht gegen Seemacht. Kaiser Sigismunds Kontinentalsperre gegen Venedig, 1412-1433 / W. Stromer // Zeitschrift für historische Forschungen. $-1995 .-$ Bd. 2. - S. 145-187.

\section{REFERENCES}

1. Grekov I.B. Ocherki po istorii mezhdunarodnykh otnosheniy Vostochnoy Evropy $X I V-X V I v v$. [Essays on the History of International Relations in Eastern Europe of the $14^{\text {th }}-16^{\text {th }}$ Centuries]. Moskow, Izd-vo vost. lit. Publ., 1963. 376 p.

2. Pashkin N.G. Vizantiya v evropeyskoy politike pervoy poloviny XV v. (1402-1438) [Byzantium in the European Politics of the First Half $\mathrm{XV}^{\text {th }}$ Century (1402-1438)]. Ekaterinburg, Izd-vo Ural. un-ta, 2007. 238 p.

3. Pashkin N.G. Padenie Konstantinopolya i krizis ideologii imperskogo universalizma na latinskom Zapade [The Fall of Constantinople and the Crisis of Imperial-Universal Ideology in the Latin West]. Izvestiya Uralskogo federalnogo universiteta. Seriya 2, Gumanitarnye nauki [Izvestia. Ural Federal University Journal. Series 2: Humanities and Arts], 2012, vol. 14, no. 2(102), pp. 109-117.

4. Pashkin N.G. Greko-Latinskaya uniya na Konstantsskom sobore v zerkale polsko-tevtonskikh otnosheniy [Greek-Latin Union at the Council of Constance in the Mirror of Polish-Teutonic Relations]. Antichnaya drevnost i srednie veka [Antiquity and the Middle Ages], 2015, vol. 43, pp. 320-328. DOI : https://doi.org/10.15826/adsv.2015.43.019.

5. Pashkin N.G. Osmanskoye «mezhdutsarstvie» 1402-1413 gg.: mezhdunarodno-politicheskiy aspekt [Ottoman "Interregnum" in 1409-1413: The International Aspect]. Antichnaya drevnost i srednie veka [Antiquity and the Middle Ages], 2018, vol. 46, pp. 225-240. DOI : https://doi.org/10.15826/adsv.2018.46.015.

6. Cherkasov D.N. Arrasskiy dogovor 1435 g. v istorii diplomatii Stoletney voyny [The Treaty of Arras of 1435 in the History of Diplomacy of the Hundred Years's War]. Zhurnal mezhdunarodnogo prava $i$ mezhdunarodnykh otnosheniy [Journal of International Law and International Relations], 2012, no. 4, pp. 43-84.

7. Finke H., ed. Acta Concilii Constanciensis. Münster, Druck und Verlag der Regensburgschen Buchhandlung, 1896. 444 p.

8. Angermeier H. Das Reich und der Konziliarismus. Historische Zeitschrift, 1961, vol. 192, pp. 541-584.

9. Baum W. Europapolitik im Vorfeld der Frühen Neuzeit: König und Kaiser Sigismund vom Hause Luxemburg, Ungarn, Byzanz und der Orient. Donnert E., ed. Europa in der Frühen Neuzeit. Vol. 1: Vormoderne. Weimar, Verl. Böhlau, 1997, pp. 13-41.

10. Boockmann H. Zur politischen Geschichte des Konstanzer Konzils. Zeitschrift für Kirchengeschichte, 1974, vol. 85, pp. 45-63.

11. Brandmüller W. Das Konzil von Konstanz. Vol. 2 : Bis zum Konzilsende. Paderborn, Schöningh, 1997. 429 p. 


\section{ВИЗАНТИЙСКОЕ ПРАВОСЛАВИЕ}

12. Prochaka A., ed. Codex epistolaris Vitoldi Magni ducis Lithuaniae, 1376-1430. Krakow, Academia Literarum, 1882.1113 p.

13. Wohlmuth J., ed. Dekrete der ökumenischen Konzilien. Vol. 2: Konzilien des Mittelalters. Paderborn, Schöningh, 2000.655 p.

14. Beckmann G., ed. Deutsche Reichstagsakten. Gotha, Friedrich Andreas Perthes, 1957. 427 p.

15. Dölger F. Regesten der Kaiserurkunden des oströmischen Reiches von 565 bis 1453. T. 5. München; Berlin, Verl. C.H. Beck, 1965. 138 p.

16. Cugnoni J., ed. Enea Silvio Piccolomini. Opera inedita. Roma, Accademia Nazionale dei Lincei, $1883.371 \mathrm{p}$.

17. Forstreuter K. Der Deutsche Orden und die Kirchenunion während des Basler Konzils. Annuarium Historiae Conciliorum, 1969, vol. 1, pp. 114-139.

18. Heimpel H. Zur Handelspolitik Kaiser Sigismunds. Vierteljahrschrift für Sozial- und Wirtschaftsgeschichte, 1930, vol. 23, pp. 145-156.

19. Helmrath J. Das Basler Konzil 1431-1449: Forschungsstand und Probleme. Köln, Böhlau, 1987. $656 \mathrm{p}$.

20. Helmrath J. Locus Concilii. Die Ortswahl für Generalkonzilien vom IV Lateranum bis Trient. Annuarium Historiae Conciliorum, 1995/1996, vol. 27/28, pp. 593-662.
21. Jablonowski H. Westrussland zwischen Wilna und Moskau: die politische Stellung und die politischen Tendenzen der russischen Bevölkerung des Grossfürstentums Litauen im 15. Jh. Leiden, E. J. Brill, $1955.167 \mathrm{p}$.

22. Kissling H.J. Venedig und der islamische Orient bis 1500. Pertusi A., ed. Venezia e il Levante fino al secolo XV. Vol. 1. Firenze, Olschki, 1973, pp. 361-387.

23. Leidl A. Die Einheit der Kirchen auf den spätmittelalterlichen Konzilien: von Konstanz bis Florenz. Paderborn, Verl. Bonifacius-Druckerei, 1966.233p.

24. Meuthen E. Eugen IV, Ferrara-Florenz und der lateinische Westen. Annuarium Historiae Conciliorum, 1990, vol. 22, pp. 219-233.

25. Palacký F., ed. Monumenta Conciliorum Generalium saeculi decimi quinti. Bd. 2. Wien, Typ. Aulae et Status, 1873. $1224 \mathrm{p}$.

26. Schiff O. König Sigmunds italienische Politik bis zur Romfahrt (1410-1431). Frankfurt/M, Verl. von Joseph Bauer, 1909. 155 p.

27. Schoenstedt F. König Siegmund und die Westmächte 1414-1415. Die Welt als Geschichte, 1954, vol. 14, pp. 149-164.

28. Stromer W. Landmacht gegen Seemacht. Kaiser Sigismunds Kontinentalsperre gegen Venedig, 1412-1433. Zeitschrift für historische Forschungen, 1995, vol. 2, pp. 145-187.

\section{Information About the Author}

Nikolai G. Pashkin, Candidate of Sciences (History), Associate Professor, Department of the History of the Ancient World and Middle Ages, Ural Federal University, Prosp. Lenina, 51, 620083 Yekaterinburg, Russian Federation, ngpaschkin@yandex.ru, https://orcid.org/0000-0003-0615-568X

\section{Информация об авторе}

Николай Геннадьевич Пашкин, кандидат исторических наук, доцент кафедры истории Древнего мира и Средних веков, Уральский федеральный университет, просп. Ленина, 51, 620083 г. Екатеринбург, Российская Федерация, ngpaschkin@yandex.ru, https://orcid.org/0000-0003-0615-568X 